\title{
Erroneous values for the total white cell count and ESR in patients with cryoglobulinaemia
}

\author{
M. R. HAENEY \\ From The Metabolic Unit, East Birmingham Hospital, Birmingham 9
}

SYNOPSIS Temperature dependent fluctuations in the erythrocyte sedimentation rate were noted during the assessment of one patient with symptomatic cryoglobulinaemia. Two patients with this condition were found to have erroneously high leucocyte counts when estimated by the Model Coulter Counter. The artefact was directly related to the degree of exposure to cold before the esti ${ }^{-}$ mation was performed and appeared to be due to the formation of microaggregates of cryoglobulin $\vec{P}$ and fibrinogen.

Cryoglobulins are cold-precipitable immunoglobulins which redissolve at warm temperatures. These serum proteins have been described in a variety of clinical conditions in man (Ritzman and Levin, 1961), but particularly in individuals with various infections, autoimmune and neoplastic disorders (Mackay et al, 1956; Meltzer et al, 1966; Barnett et al, 1970).

In assessing one patient with symptomatic cryoglobulinaemia, fluctuations in the erythrocyte sedimentation rate were noted. In addition, the same patient demonstrated erroneously high leucocyte counts when the Model S Coulter Counter was used but normal values when counting was performed by hand. The variations in ESR and WBC counts were found to be temperature dependent and thus susceptible to environmental conditions. A further patient with symptomatic cryoglobulinaemia also showed similar changes in leucocyte counts.

\section{Case reports}

CASE 1

J.P., a 60-year-old car worker, presented in September 1973 with a two-year history of recurrent chest infections and a six-month story of Raynaud's phenomenon affecting his hands, feet, and face. Preliminary investigations at a different hospital had been passed as normal. In particular, the erythrocyte sedimentation rate was $20 \mathrm{~mm}$ fall in one hour. He was discharged from follow-up but because of the persistence of symptoms he was referred to this department by his family doctor. Physical examination was non-contributory. Rou-

Received for publication 11 March 1976 tine investigation showed marked fluctuations in ESR (20-120 mm fall/1 hour) and total white celf count $\left(6-18 \times 10^{9}\right.$ cells/l) on a day-to-day basis. Hळ was subsequently found to have a monoclonal IgCD paraproteinaemia with cryoglobulinaemia. The mean quantitative serum IgG level was 24 if (normal 6-16 g/1); mean IgA 0.29 g/1 (0.75-5.2); IgM? $0.08 \mathrm{~g} / 1(0.3-1.8)$. The serum cryoglobulin como sisted of monoclonal IgG in a concentration $\exists$ $21.4 \mathrm{~g} / \mathrm{l}$. Increased numbers of atypical IgG staine ing plasma cells were present in the bone marrovo and a pathological fracture of the right third rito was demonstrated radiologically. The patient wast considered to have multiple myelomatosis with cryo 3 globulinaemia. The disturbing variation in results? obtained for the ESR and leucocyte counts prompted. this study of the effect of temperature on these para meters in the patient.

CASE 2

B.S., a 45-year-old woman of Russian extraction, presented in August 1974 with the nephrotic syndrome. In the preceding 15 years she had experienced two episodes of an intermittent purpuric erythes matous papular eruption on the legs with a bilateraf arthropathy affecting the knees and ankles. A skif̧ biopsy was compatible with the diagnosis of allergif vasculitis. Renal function was normal at this time but the Rose-Waaler test was positive at a titre of $1 / 128$. A trace of cryoglobulin was found in the serum six years before the present admission. She responded to systemic steroids which were dis continued after 12 months.

In 1974 she presented with ankle oedema of eight months' duration. She was found to have a nephrotie syndrome with non-selective massive proteinuria of 
10-15 g per 24 hours. The creatinine clearance was initially $70 \mathrm{ml} / \mathrm{min}$ but later rose with treatment to over $100 \mathrm{ml} / \mathrm{min}$. The Rose-Waaler was positive at a titre of $1 / 128$. The serum immunoglobulins were abnormal: lgG $2.08 \mathrm{~g} / 1$ (normal 6-16); $\operatorname{lgA} 0.83 \mathrm{~g} / \mathrm{l}$ $(0 \cdot 75-5 \cdot 2)$; IgM 2.24 g/l (0.3-1.8). Complement levels were low: $\mathrm{C} 3$ was $0.51 \mathrm{~g} / 1$ (normal $0 \cdot 78-1 \cdot 61$ ) and $\mathrm{C} 4$ was remarkably low at $0.01 \mathrm{~g} / \mathrm{l}(0 \cdot 15-0.45)$; Clq was also low. The serum contained a mixed cryoglobulinaemia composed of monoclonal IgM, type kappa (mean concentration $2.8 \mathrm{~g} / \mathrm{l}$ ) and IgG (mean concentration $1.5 \mathrm{~g} / \mathrm{l})$. Increased numbers of plasma cells staining with IgM and IgG and normal numbers of $\operatorname{IgA}$ staining plasma cells were seen on bone marrow immunofluorescence. A skin biopsy revealed scattered deposition of coarse aggregates of IgM and IgG and, to a very small extent, of complement. These aggregates were related to blood vessels. The histology of the renal biopsy was that of membranoproliferative glomerulonephritis, and on immunofluorescence granular deposits of IgG and IgM were seen on the epithelial basement membrane. Complement staining was remarkably faint. It thus appears that this patient has a 'soluble immune complex disease' due to the mixed cryoglobulinaemia with cutaneous vasculitis, an arthropathy, and membranoproliferative glomerulonephritis producing a nephrotic syndrome. Routine assessment of this patient also revealed fluctuations in leucocyte counts seen previously in case 1.

\section{Methods}

Blood was drawn in prewarmed $\left(37^{\circ} \mathrm{C}\right)$ tubes containing potassium EDTA and maintained at $37^{\circ} \mathrm{C}$. Thereafter blood was divided into four samples; one sample was kept at $37^{\circ} \mathrm{C}$ and the others were cooled to $20^{\circ} \mathrm{C}, 12^{\circ} \mathrm{C}$, or $4^{\circ} \mathrm{C}$. All samples were maintained at these temperatures for one hour before the estimation of erythrocyte sedimentation rate and white cell count. The ESR was then simultaneously estimated for each sample at $20^{\circ} \mathrm{C}$ in a $200 \mathrm{~mm}$ column. The Westergren method was used with sodium citrate $3.8 \%$ solution to make a $20 \%$ dilution of blood. The reading was taken at one hour.

In the two patients with cryoglobulinaemia, total leucocyte counts were also estimated on the four samples using a Model S Coulter Counter.

\section{Results}

ERYTHROCYTE SEDIMENTATION RATES (table I)

Group I: Normal controls

Twenty normal controls were evaluated. These con- sisted of members of staff and informed hospital inpatients. The mean ESR for the group at one hour showed a gradual rise with increasing temperature up to $20^{\circ} \mathrm{C}$, though all results were within the normal range. At $37^{\circ} \mathrm{C}$ the ESR was mildly increased.

\begin{tabular}{|c|c|c|c|c|c|c|}
\hline \multirow[t]{2}{*}{ Group } & \multirow{2}{*}{$\begin{array}{l}\text { No. of } \\
\text { estimations }\end{array}$} & \multirow{2}{*}{$\begin{array}{l}\text { Erythrocyte } \\
\text { sedimenta- } \\
\text { tion rate } \\
(\mathrm{mm} \text { fall/hr) }\end{array}$} & \multicolumn{4}{|c|}{ Temperature $\left({ }^{\circ} \mathrm{C}\right)$} \\
\hline & & & 4 & 12 & 20 & 37 \\
\hline $\begin{array}{l}\text { I Normal } \\
\text { Control }\end{array}$ & 20 & $\begin{array}{l}\text { Mean } \\
\text { SEM }^{1}\end{array}$ & $\begin{array}{l}6 \cdot 2 \\
1.0\end{array}$ & $\begin{array}{l}7.6 \\
1.4\end{array}$ & $\begin{array}{l}9 \cdot 9 \\
2 \cdot 0\end{array}$ & $\begin{array}{r}16 \cdot 1 \\
2 \cdot 6\end{array}$ \\
\hline $\begin{array}{l}\text { II Non- } \\
\text { specific } \\
\text { increase }\end{array}$ & 5 & $\begin{array}{l}\text { Mean } \\
\text { SEM }\end{array}$ & $\begin{array}{r}39 \cdot 0 \\
7 \cdot 6\end{array}$ & $\begin{array}{l}75 \cdot 2 \\
12 \cdot 1\end{array}$ & $\begin{array}{l}90 \cdot 6 \\
10 \cdot 6\end{array}$ & $\begin{array}{r}107 \cdot 6 \\
10 \cdot 1\end{array}$ \\
\hline $\begin{array}{l}\text { III Cryo- } \\
\text { globulin- } \\
\text { aemia }\end{array}$ & 6 & $\begin{array}{l}\text { Mean } \\
\text { SEM }\end{array}$ & $\begin{array}{l}5 \cdot 6 \\
1 \cdot 4\end{array}$ & $\begin{array}{r}17 \cdot 0 \\
5 \cdot 4\end{array}$ & $\begin{array}{l}40 \cdot 8 \\
12 \cdot 7\end{array}$ & $\begin{array}{r}111 \cdot 8 \\
8 \cdot 3\end{array}$ \\
\hline
\end{tabular}

Table I Effect of temperature variation on ESR in case 1, normal controls, and patients with other causes of an increased ESR

${ }^{1} \mathrm{SEM}=$ standard error of mean

Group II: Non-specific increase of ESR

Five patients with increased ESRs made up the group. An increase, in the terms of this study, was defined as an ESR in excess of $50 \mathrm{~mm}$ fall in one hour on three or more occasions. Cryoglobulinaemia was excluded in all cases. The ESR was grossly increased at all temperatures, the values at $4^{\circ} \mathrm{C}, 12^{\circ} \mathrm{C}$, and $20^{\circ} \mathrm{C}$ being approximately $35 \%, 70 \%$, and $85 \%$ respectively of the value obtained at $37^{\circ} \mathrm{C}$.

\section{Group III: Cryoglobulinaemia}

Case 1 was studied on six occasions. In contrast to group II patients, the ESR at $4^{\circ} \mathrm{C}$ was normal and was only $4 \%$ of the ESR at $37^{\circ} \mathrm{C}$. Similarly, at $12^{\circ} \mathrm{C}$ the ESR was only slightly increased and represented $15 \%$ of the value at $37^{\circ} \mathrm{C}$. Even at $20^{\circ} \mathrm{C}$ the result was less than $40 \%$ of the ESR at $37^{\circ} \mathrm{C}$ and less than $50 \%$ of the corresponding values obtained in group II patients. However, at $37^{\circ} \mathrm{C}$ the ESR in the patient with cryoglobulinaemia was higher than the mean obtained for group II.

TOTAL WHITE CELL COUNTS (table II)

Total leucocyte counts were studied in the two patients with cryoglobulinaemia. The pattern obtained was similar in both cases. The counts were normal at $37^{\circ} \mathrm{C}$ using the Model S Coulter Counter. However, as the temperature was lowered, the total WBC counts rose to abnormal levels even after one hour at $20^{\circ} \mathrm{C}$ and reached values in excess of $20 \times$ $10^{9}$ cells $/ 1$ after one hour at $4^{\circ} \mathrm{C}$. The values obtained 
by a manual method were normal at all temperatures in both patients.

\begin{tabular}{|c|c|c|c|c|c|c|}
\hline \multirow[t]{2}{*}{$\overline{\text { Case }}$} & \multirow{2}{*}{$\begin{array}{l}\text { No. of } \\
\text { estimations }\end{array}$} & \multirow{2}{*}{$\begin{array}{l}\text { Total leuco- } \\
\text { cyte counts } \\
\times 10^{\circ} / l\end{array}$} & \multicolumn{4}{|c|}{ Temperature $\left({ }^{\circ} \mathrm{C}\right)$} \\
\hline & & & 4 & 12 & 20 & 37 \\
\hline 1 & 6 & $\begin{array}{l}\text { Mean } \\
\text { SEM }^{1}\end{array}$ & $\begin{array}{r}24 \cdot 0 \\
4 \cdot 1\end{array}$ & $\begin{array}{r}13.3 \\
1.6\end{array}$ & $\begin{array}{r}11.5 \\
1.3\end{array}$ & $\begin{array}{l}6 \cdot 3 \\
1 \cdot 1\end{array}$ \\
\hline 2 & 10 & $\begin{array}{l}\text { Mean } \\
\text { SEM }\end{array}$ & $\begin{array}{r}21.9 \\
3.4\end{array}$ & $\begin{array}{r}17 \cdot 7 \\
2.6\end{array}$ & $\begin{array}{r}14.9 \\
2.3\end{array}$ & $\begin{array}{l}9.5 \\
0.8\end{array}$ \\
\hline
\end{tabular}

Table II Leucocyte counts obtained on the Model ' $S$ ' Coulter Counter in two patients with cryoglobulinaemia

${ }^{1}$ SEM $=$ standard error of mean

\section{Discussion}

Erythrocyte sedimentation rate is known to vary with room temperature (Rogers, 1946; Wartman, 1946), and Manley (1957) has prepared a nomogram for the correction of ESR by Westergren's method for temperature variations. The results obtained in this present study for groups I and II show a close correlation with the nomogram, the actual rise in ESR with temperature being similar to the predicted value. In contrast, the patient with cryoglobulinaemia gave results which failed to correlate with the correction graph, the readings at $20^{\circ} \mathrm{C}$ and $12^{\circ} \mathrm{C}$ underestimating the true ESR. In cryoglobulinaemic patients a false normal ESR may result if samples are allowed to stand at low temperatures for even a short time.

The same patient (case 1) also manifested considerable variation in the total white cell count on consecutive days when estimated by the Model $\mathbf{S}$ Coulter Counter. Manual leucocyte counts were repeatedly within the normal range. These spurious results have been shown to be temperature dependent (table II). Immediate estimations of the white cell count were normal on the automated counter but rose progressively if the samples were allowed to stand for one hour at low temperatures. If the samples, even after the cooling period, were warmed to $37^{\circ} \mathrm{C}$ before counting, or if warm diluent was used, then normal leucocyte counts were obtained. The conclusion is that the cryoglobulinaemia is responsible for this spurious leucocytosis. This was confirmed in the second patient with 'essential' cryoglobulinaemia. In case 2 , it was found that if serum was separated from whole blood, and plasma separated from EDTA anticoagulated whole blood, then the leucocyte counts of both serum and plasma were similar if estimated immediately in the Coulter Counter. If samples were allowed to stand for one hour at lower temperatures, as described, then only the plasma samples showed a spurious leucocytosis on the automated counter. This artefact was temp erature dependent. It seems likely that the increased leucocyte counts may not be due to cryoglobulin alone but to microaggregates between cryoglobulin? and fibrinogen. These findings confirm those of other workers who have shown spurious leucocytosiso in cryoglobulinaemic patients (Emori et al, 1973) $\overline{\bar{p}}$ Taft et al (1973) described one patient with a spon-ه taneously crystallizing paraproteinaemia in whom the leucocytosis was due to needle crystals of cryo- globulin appearing when blood was stored at $24^{\circ} \mathrm{C}$ but did not occur even after refrigeration to $4^{\circ} \mathrm{C}$ for $\overrightarrow{-}$ 6 hours. This appeared to be related to the size and shape of the crystals produced.

A feature of chilled blood containing cryo globulins is that platelet aggregation may occure sometimes to a striking degree (Cortellaro et al, $\vec{\circ}$ 1975). However, the platelet aggregation describeco by Cortellaro et al is not reversible and is inhibited completely in the presence of EDTA. Visual ands automated platelet counts at different temperatures have been performed on one patient (case 1). Non significant difference was found in the values obtained at $4^{\circ} \mathrm{C}, 12^{\circ} \mathrm{C}$, and $20^{\circ} \mathrm{C}$. Although plateleథ aggregates, with their lipid membranes, are likely to interfere with the electric current in the automagic counter, this does not appear to be the explanation in the cases reported.

For the estimation of leucocyte counts in patie known to have cryoglobulinaemia manual methods should be used or blood maintained at $37^{\circ} \mathrm{C}$ untip estimated by the Model S Coulter Counter. Alterna tively, warming the diluent entering the counter to $\vec{\sigma}$ $37^{\circ} \mathrm{C}$ eliminates the error. Inappropriately increased $B$ leucocyte counts should alert the clinician that cryoglobulin may be present. In addition, in one of the patients described, the ESR showed fluctuations not seen in patients with increased sedimentation rates due to other causes. Environmental cooling ob the blood before estimation of the ESR can produce values that may be interpreted as normal. This dich occur in the case described, with subsequent delay in diagnosis and treatment.

I am grateful to Professor John Hardwicke fo permission to study the patients under his care and for his help, advice, and encouragement. Dr R. AN Thompson, of the Regional Immunology Labora tory, kindly performed the immunological investiga $\omega$ tions on the patients.

\section{References}

Barnett, E. V., Bluestone, R., Cracchiolo, A., Goldberge L. S., Kantor, G. L., and McIntosh, R. M. (1970). Cryo $\$$ globulinemia and disease. Ann. intern. Med., 73, 95-107. 
Cortellaro, M., Lambertenghi-Deliliers, G., Cofrancesco, E., Pogliani, E., Pozzoli, E., Imbasciati, E., and Praga, C. (1975). Human platelet aggregation by mixed cryoglobulins. Acta haemat. (Basel), 54, 36-45.

Emori, H. W., Bluestone, R., and Goldberg, L. S. (1973). Pseudo-leukocytosis associated with cryoglobulinaemia. Amer. J. clin. Path., 60, 202-204.

Mackay, I. R., Eriksen, S., Motulsky, A. G., and Volwiler, W. (1956). Cryo- and macro-globulinemia. Electrophoretic, ultracentrifugal and clinical studies. Amer. J. Med., 20, 564-587.

Manley, R. W. (1957). The effect of room temperature on erythrocyte sedimentation rate and its correction. J. clin. Path., 10, 354-356.

Meltzer, M., Franklin, E. C., Elias, K., McClusky, R. T., and
Cooper, N. (1966). Cryoglobulinemia: a clinical and laboratory study. II Cryoglobulins with rheumatoid factor activity. Amer. J. Med., 40, 837-856.

Ritzman, S. E. and Levin, W. C. (1961). Cryopathies: a review. Classification, diagnostic and therapeutic considerations. Arch. intern. Med., 107, 754-772.

Rogers, K. B. (1946). Effect of temperature on sedimentation rate. Lancet, 2, 520-522.

Taft, E. G., Grossman, J., Abraham, G. N., Leddy, J. P., and Lichtman, M. A. (1973). Pseudoleucocytosis due to cryoprotein crystals. Amer. J. clin. Path., 60, 669-671.

Wartman, W B. (1946). Effect of room temperature on sedimentation rate of red blood cells of man. Amer. J. med. Sci., 212, 207-210. 